J. Clin. Chem. Clin. Biochem.

Vol. 20, 1982, pp. $91-94$

\title{
Enzyme Enhanced Luminescence Immunoassay for the Determination of Transferrin Concentrations in Serum
}

\author{
By H. Fricke, Chr. J. Strasburger and W. G. Wood \\ Klinik für Innere Medizin (Direktor: Prof. Dr. Peter C. Scriba), Medizinische Hochschule Lübeck
}

(Received October 8/November 27, 1981)

Summary: An enzyme enhanced luminescence immunoassay has been developed using the determination of serum transferrin as a model. The assay has been compared with an established radioimmunoassay, the details of which have already been published (Wood, W. G. et al. (1980) Fresenius Z. Anal. Chem. 301, 120). After comparison, the luminescence immunoassay was introduced as the routine method for determining transferrin levels in human serum.

The enzyme enhanced luminescence immunoassay uses a pyruvate kinase labelled transferrin as tracer, which, after the antibody-antigen reaction and subsequent bound-free separation, is used to generate adenosine triphosphate (ATP) from adenosine diphosphate (ADP) and phosphoenol pyruvate. The ATP is then monitored with a firefly luciferin-luciferase reagent, using a luminometer as detection system.

The intra- and interassay coefficients of variation were under $10 \%$ and under $13 \%$ respectively in the range $0.6-$ $4.5 \mathrm{~g} \cdot$ liter $^{-1}$. The stability of the lyophilised tracer was in excess of 5 months when stored at $4{ }^{\circ} \mathrm{C}$, and the sensitivity of the assay lay under $0.1 \mu \mathrm{g}$ per tube, although the detection limit of this type of assay system has not been fully explored.

\section{Ein enzympotenzierter Lumineszenzimmunoassay für die Bestimmung von Transferrin im Serum}

Zusammenfassung: Es wurde ein enzympotenzierter Lumineszenzimmunoassay für die Bestimmung von Serumtransferrin entwickelt. Dieser neue Assay wurde mit einem Routine-Radioimmunoassay verglichen, dessen Einzelheiten bereits veröffentlicht sind (Wood, W. G. et al. (1980) Fresenius Z. Anal. Chem. 301, 120). Später wurde der Lumineszenzimmunoassay als Routinemethode eingesetzt.

Der enzympotenzierte Lumineszenzimmunoassay verwendet ein Pyruvatkinase-Transferrin-Konjugat als Tracer. Als Maß für die Antigenkonzentration im Serum wird die Adenosintriphósphat (ATP) Erzeugung der Pyrụvatkinase nach der Immunreaktion verwendet. Das entstandene ATP wird in einem Luciferin-Luciferase System umgesetzt und das produzierte Licht in einem Luminometer gemesșen. Die Ergebnisse des enzympotenzierten Lumineszenzimmunoassay korrelierten sehr gut mit denen des Radioimmunoassays. Der Variationskoeffizient sowohl für Intra- als für Interassay-Bestimmungen lag unter 10 bzw. $13 \%$ im Konżentrationsbereich von 0,6 bis $4,5 \mathrm{~g} \cdot \operatorname{liter}^{-1}$.

Die Stabilität des lyophilisierten Konjugates liegt weit über fünf Monate und die Empfindlichkeit des Assays liegt unter 0,1 $\mu \mathrm{g}$ pro Röhrchen, wobei die wirkliche Nachweisgrenze dièser Assaysysteme noch nicht erforscht ist.

\section{Introduction}

This article describes an alternative to radioimmunoassay using a combination of enzyme and luminescence techniques which form the basis of the enzyme enhanced luminescence immunoassay. The choice of transferrin as parameter was twofold, namely to reduce the need for a radioactive tracer, which had to be produced in the laboratory, and to set up a robust assay system which would work under routine conditions. At this stage, the detection limits of the system were of secondary importance.
This type of assay is not as susceptible to quench effects often seen in chemiluminescence immunoassays (2-4) making it possible to measure serum proteins and hormones.

The principle of the test is a combination of an enzymelabelled antigen using pyruvate kinase (EC 2.7.1.40) coupled to an ATP dependent luciferin-luciferase system. The rate of ATP formation from ADP and phosphoenol pyruvate is proportional to the light intensity and inversely proportional to the concentration of nonlabelled antigen in the system when the antibody-bound fraction is measured. 


\section{Materials and Methods}

Human transferrin was obtained form Behringwerke, Marburg a.d. Lahn, FRG.

Crystalline pyruvate kinase and $m$-maleimidobenzoyl-N-hydroxysuccinimide ester were purchased from Sigma, Munich, FRG. Suspensions of pyruvate kinase were obtained from BoehringerMannheim, Mannheim, FRG.

The luciferin-luciferase reagent was generously donated by LKB Munich, FRG.

All buffer reagents were purchased from Merck, Darmstadt, FRG. Ultrogel A6 chromatography gel was purchased from LKB, Düsseldorf, FRG.

Antibodies were raised in rabbits using human transferrin as immunogen in Freund's complete adjuvant. The antisera were used at an initial dilution of $1: 1000$.

The luminometer was provided by LKB-Wallac, Turku, Finland, and was connected to a plotter and an integrator-printer, (Type 1250 Luminometer and plotter, with Datec integrator-printer).

The start reagent (ADP-phosphoenol pyruvate) was dispensed from a Microlab P (Hamilton, Bonaduz, Switzerland).

Radioactive transferrin tracer was prepared as already published (1).

\section{Preparation of the pyruvate kinase labelled transferrin}

$1 \mathrm{ml}$ human transferrin solution $(1 \mu \mathrm{mol})$ was coupled to $70 \mu \mathrm{l}$ $(1.2 \mu \mathrm{mol}) m$-maleimidobenzoyl-N-hydroxy-succinimide ester at $\mathrm{pH} 7.0$ in $0.1 \mathrm{~mol} / 1$ phosphate buffer using the method of Kitagawa (5). After coupling, the mixture was dialysed against $0.1 \mathrm{~mol} / 1$ phosphate buffer, $\mathrm{pH} 7.0$ to remove unreacted $m$-maleimidobenzoyl- $\mathrm{N}$-hydroxy-succinimide ester and tetrahydrofurane. $25 \mathrm{nmol}$ pyruvate kinase was added to the transferrin- $m$-maleimidobenzoyl-N-hydroxy-succinimide and allowed to react for $30 \mathrm{~min}$ at ambient temperature, followed by $18 \mathrm{~h}$ at $4{ }^{\circ} \mathrm{C}$. The product so formed was separated on an Ultrogel $\mathrm{A} 6$ column $(60 \times 2 \mathrm{~cm})$ using $0.02 \mathrm{~mol} / 1$ phosphate buffer containing $0.1 \mathrm{~mol} \cdot$ liter $^{-1} \mathrm{NaCl}, \mathrm{pH}$ 7.0. The fractions $(2 \mathrm{ml}$ ) were collected and tested for pyruvate kinase activity and for immunoreactive transferrin, after a prior dilution of $1: 500$. The fractions containing pyruvate kinase activity and transferrin were pooled, lyophilised and stored at $4{ }^{\circ} \mathrm{C}$ until use.

\section{Preparation of solid-phase second antibody}

$20 \mathrm{~g}$ microcrystalline cellulose (Sigma) were suspended in $100 \mathrm{ml}$ $0.05 \mathrm{~mol} / 1$ borate buffer, $\mathrm{pH} 6.0$ and $100 \mathrm{mg} \mathrm{NaIO}{ }_{4}$ added. The mixture was stirred and kept at $70^{\circ} \mathrm{C}$ for 2 hours. The presence of aldehyde groups was monitored using Schiff's reagent ( $p$-rosaniline saturated with $\mathrm{SO}_{2}$ ). The oxidation of the vicinal hydroxylgroups of the cellulose matrix was seen by an increasing violet coloration of the mixture. The reaction was completed after ca. 90 minutes. The microcrystalline cellulose was centrifuged, the supernatant removed and the precipitate washed twice with distilled water. The precipitate was then resuspended in $200 \mathrm{ml}$ $0.05 \mathrm{~mol} / 1 \mathrm{Na}_{2} \mathrm{~B}_{4} \mathrm{O}_{7}, \mathrm{pH} 9.35$ and $100 \mathrm{mg} \gamma$-globulin fraction of the second antibody (donkey-anti rabbit IgG) added. The mixture was stirred for 24 hours at $4{ }^{\circ} \mathrm{C}$ after which it was tested for free aldehyde groups as above. If the reaction was positive, ethanolamine ( $1 \mathrm{~mol} / 1, \mathrm{pH} 9.35$ ) was added until the Schiff-reaction remained negative. The slurry was then washed as above, finally being suspended in $200 \mathrm{ml} \mathrm{H}_{3} \mathrm{BO}_{3}(0.05 \mathrm{~mol} / 1, \mathrm{pH}$ 5.2) and $200 \mathrm{mg} \mathrm{NaBH}_{4}$ added to stabilise the Schiff bases formed during the coupling. The mixture was stirred for $30 \mathrm{~min}$ at ambient temperature, being then washed as above, finally being suspended in $100 \mathrm{ml} 0.05 \mathrm{~mol} / 1$ phosphate buffer, $\mathrm{pH} 7.5$ containing bovine serum albumin $\left(5 \mathrm{~g} \cdot\right.$ liter $\left.^{-1}\right)$ to saturate any active sites. Before use in the assay the slurry was further diluted $1: 10$ with potassium phosphate buffer $(0.05 \mathrm{~mol} / 1, \mathrm{pH} 7.8)$.

\section{Enzyme enhanced luminescence and radioimmunoassays for transferrin}

The radioimmunoassay was performed as already published (1) with the following changes: The serum samples were diluted
1:100 before assay and the separation of bound and free antigen was carried out using the solid phase second antibody described above. The luminescence immunoassay was carried out identically with the radioimmunoassay with the exception of the tracer. The assays are summarised below:

$20 \mu l$ serum or standard (diluted $1: 100$ in $0.15 \mathrm{~mol} / 1 \mathrm{NaCl}$ containing EDTA $(0.01 \mathrm{~mol} / \mathrm{l}))$.

$50 \mu$ antiserum (1:1000 dilution in $0.05 \mathrm{~mol} / 1$ potassium phosphate buffer, $\mathrm{pH} 7.8$ containing $0.2 \mathrm{~g} \cdot$ liter $^{-1}$ bovine serum albumin), i 1

$50 \mu \mathrm{l}$ tracer $(40,000$ counts/min or ca. 2 pmol pyruvate kinasetransferrin).

Allow to react for 45 minutes at ambient temperature

$200 \mu l$ solid phase second antibody

Allow to stand for 30 min with occasional agitation.

Add $1 \mathrm{ml} 0.15 \mathrm{~mol} / 1 \mathrm{KCl}$ and centrifuge for $7 \mathrm{~min}$ at $3000 \mathrm{~g}$.

Aspirate off the supernate and rewash the precipitate with $\mathrm{KCl}$ as above, centrifuging and discarding the supernate.

The radioimmunoassay was then counted in a multi-channel gamma counter (Nuclear Enterprises Type NE 1600) for 1 minute, the data processing being carried out on-line with a CBM 4032 desk top computer using a spline function (6) with an adapted programme described by Marschner et al. (7), in which an automatic smoothing routine had been iñcorporated.

The luminescence immunoassay precipitates were treated as follows after the $\mathrm{KCl}$ wash sequence:

$400 \mu \mathrm{l}$ Tris-HCl buffer $(0.1 \mathrm{~mol} / 1, \mathrm{pH} 7.8)$ containing EDTA $(0.01 \mathrm{~mol} / \mathrm{l})$ and

$200 \mu$ l of a mixture of ADP, phosphoenol pyruvate (both

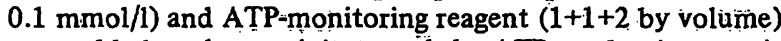
were added to the precipitate and the ATP production monitored in the luminometer with plọtter trace and 10 second integral print-outs.

The rate of ATP production was expressed as $\mathrm{mV} \cdot \mathrm{s}^{-1}$. The reaction was followed from the 31 st to the 60 th seconds over 3 successive 10 second periods, the mean $\overline{m V}$ change for each period calculated, checked for linearity and the mean value used for data processing.

\section{Results}

\section{Constancy of ATP production}

In a series of 1000 measurements, the variation of the slope $\mathrm{dV} / \mathrm{dt}$ was under $1 \%$ in each case for the time interval 31-60 seconds for the 3 successive time intervals of 10 seconds, i.e. the slope was fully linear during the period of measurement.

\section{Intra- and inter-assay coefficients of variation}

The intra-assay coefficient of variation (CV) measured at three points along the standard curve was as follows:

Test serum 1: mean $4.08 \mathrm{~g} \cdot$ liter $^{-1}, \mathrm{CV} 7.05 \%, \mathrm{n}=20$ Test serum 2: mean $2.26 \mathrm{~g} \cdot$ liter $^{-1}, \mathrm{CV} 8.75 \%, \mathrm{n}=20$ Test serum 3: mean $0.75 \mathrm{~g} \cdot$ liter $^{-1}, \mathrm{CV} 9.70 \%, \mathrm{n}=20$ The inter-assay CV for the same control sera was as follows:

Test serum 1: mean $3.58 \mathrm{~g} \cdot$ liter $^{-1}, \mathrm{CV} 10.4 \%, \mathrm{n}=20$ Test serum 2: mean $2.13 \mathrm{~g} \cdot \operatorname{liter}^{-1}$, CV $11.8 \%, \mathrm{n}=20$ Test serum 3: mean $0.82 \mathrm{~g} \cdot$ liter $^{-1}, \mathrm{CV} 11.4 \%, \mathrm{n}=20$

The inter-assay $\mathrm{CV}$ was determined from the mean of duplicate values from each assay. 


\section{Correlation of the enzyme enhanced luminescence immunoassay with the radioimmunoassay}

The correlation between the luminescence- and radioimmunoassays was made from data from 14 assays carried out simultaneously for both methods. The only difference in the assays was the tracer. Values from the radioimmunoassay were entered as $x$, those from the luminescence immunoassay as $y .147$ serum samples were used in the comparison.

The regression line $y=a+b x$ had the following coefficients: $a=0.01, b=1.05$, with a correlation coefficient of $\mathrm{I}=0.960$. The mean value for the radioimmunoassay was $2.13 \mathrm{~g} \cdot$ liter $^{-1}$ (range $0.11-7.58 \mathrm{~g} \cdot$ liter $^{-1}$ ) and for the luminescence immunoassay $2.24 \mathrm{~g} \cdot$ liter $^{-1}$, (range $0.10-7.34 \mathrm{~g} \cdot$ liter $\left.^{-1}\right)$.

The reference range for both assays was the same, i.e. $2-4 \mathrm{~g} \cdot \mathrm{liter}^{-1}$, for persons with normal body iron status as determined for this laboratory (8).

\section{Standard curve data}

The data from two typical standard curves is shown in table 1. It can be seen that the form of the luminescence and radioimmunoassay standard curves are similar. The data is expressed in tabular form to allow a better comparison of the data received.

Tab. 1. Data from the enzyme enhanced luminescence immunoassay and radioimmunoassay standard curves - assays carried out simultaneously.

\begin{tabular}{lll}
\hline Standard transferrin & $\begin{array}{l}\text { Enzyme enhanced } \\
\text { luminescence immuno- } \\
\text { assay } \\
\text { Rate of ATP } \\
\text { production dV/dt } \\
\left(\mathrm{mV} \cdot \mathrm{s}^{-1}\right)\end{array}$ & $\begin{array}{l}\text { Radio- } \\
\text { immunoassay }\end{array}$ \\
$\mathrm{g} \cdot$ liter $^{-1}$ & 52.8 & \\
\hline 0 & 51.7 & 12545 \\
0 & 36.2 & 12169 \\
0.5 & 36.6 & 8239 \\
0.5 & 30.4 & 8260 \\
1.0 & 32.0 & 7459 \\
1.0 & 24.8 & 7429 \\
2.0 & 25.2 & 6272 \\
2.0 & 19.1 & 6382 \\
4.0 & 18.0 & 5467 \\
4.0 & 13.8 & 5195 \\
8.0 & 14.6 & 4108 \\
8.0 & 7.30 & 4098 \\
UB* & 6.68 & 2953 \\
UB & & 2791 \\
\hline
\end{tabular}

$.50 \%$ intercept - Enzyme enhanced luminescence immunoassay $0.94 \mathrm{~g} \cdot$ liter $^{-1}$, Radioimmunoassay $0.93 \mathrm{~g} \cdot$ liter $^{-1}$. Sensitivity (lower limit of detection), luminescence immunoassay and radioimmunoassay $<0.1 \mathrm{~g} \cdot$ liter $^{-1}$.

* UB - non-specific binding (antibody blank).

\section{Recovery studies on the enzyme enhanced luminescence immunoassay}

Human transferrin was added to two sera with known endogenous transferrin levels (determined as the mean values from duplicate determinations in 20 assays in the radioimmunoassay). One serum was from a patient on haemodialysis, with diminished transferrin, the other was a patient with normal body iron status (haemoglobin $149 \mathrm{~g} \cdot$ liter $^{-1}, \mathrm{Hb}_{\mathrm{E}} 32 \mathrm{pg}$, serum ferritin $102 \mu \mathrm{g} \cdot$ liter $^{-1}$

(8)). The results for the mean recovery in three successive assays is șhown in table 2.

Tab. 2. Recovery data from transferrin added to two sera at different concentrations. The results are the mean of duplicate determinations carried out in three successive assays.

Serum A had a mean value of $0.22 \mathrm{~g} \cdot$ liter $^{-1}$, serum B had a mean value of $2.24 \mathrm{~g} \cdot$ liter $^{-1}$, (both measured in duplicate in 20 assays using the radioimmunoassay as reference method).

\begin{tabular}{llll}
\hline Serum & $\begin{array}{l}\text { Transferrin added } \\
\left(\mathrm{g} \cdot \text { liter }^{-1}\right)\end{array}$ & $\begin{array}{l}\text { Transferrin found } \\
\left(\mathrm{g} \cdot \text { liter }^{-1}\right)\end{array}$ & $\begin{array}{l}\text { Recov- } \\
\text { ery }\end{array}$ \\
\hline A & 0 & 0.21 & - \\
& 0.5 & 0.69 & 0.97 \\
& 1.0 & 1.06 & 0.98 \\
& 2.0 & 2.17 & 0.98 \\
B & 5.0 & 5.04 & 0.97 \\
& 0 & 2.28 & - \\
& 0.5 & 2.79 & 1.00 \\
& 1.0 & 3.40 & 1.04 \\
& 2.0 & 4.22 & 0.99 \\
& 5.0 & 7.33 & 1.01 \\
\hline
\end{tabular}

\section{Discussion}

This article describes an alternative to radioimmunoassay for the determination of proteins in biological fluids. The system chosen with transferrin as analyte was not meant to test the potential sensitivity of the method, but rather to establish a routine assay robust enough to be carried outby all laboratory personnel. The assays correlate well with each other, the reference range not having to be changed when the luminescence immunoassay replaced the radioimmunoassay for the routine determination of serum transferrin.

Preliminary data (Fricke - unpublished data 1981) has shown that the pyruvate kinase labelled antigen coupled with the firefly luciferin-luciferase system is sensitive enough to measure insulin levels in untreated sera with an assay sensitivity of under $5 \mathrm{mU} / \mathrm{l}$, using an analogous assay system to the one here described. The advantage of the system used here, over conventional chemiluminescence immunoassays is that the quenching effect due to proteins is absent. This is due to the fact that the light-generation system is independent of the antigenantibody binding site.

The use of a solid-phase second antibody separation step allows the removal of potential interference from serum components. The use of microcrystalline cellulose as support, paradox though it may seem, does not appear to affect the linearity of the light output, although for the more sensitive assays, the volume of the second antibody must be reduced to keep potential light absorp- 
tion to a minimum. This can be done by increasing the amount of second antibody per unit mass of support, or by substituting the cellulose for a more translucent material, for example activated polymer beads.

Although this assay has been built up using pyruvate kinase as label, other enzymes with lower molecular weight appear to be better for hapten assays, for example myokinase (EC 2.7.4.3). One is not limited to the ADPATP system coupled to firefly luciferin-luciferase, and other enzymes with high turnover rates, for example glucose-6-phosphate dehydrogenase (EC 1.1.1.49) can be used coupled to an NADP-NADPH dependant bacterial luciferin luciferase system.

The main problem of introducing such assays is the problem of automation. One must compare the present state of luminescence detection systems currently available with the availability of automatic gamma-counters in the early 1960s. At the present time, there is only one automatic luminometer available (LKB 1251) which can sample 25 tubes sequentially.

The future of luminescence immunoassay lies in the availability of kits and suitable monitoring equipment, as before this, there is little incentive to change from radioimmunoassays to these alternative techniques.

\section{Acknowledgements}

The authors would like to thank Professor P. C. Scriba for his continued support and encouragement, as well as for his critical reading of this manuscript. Thanks also go to Drs. Timo Lövgren and Erkki Soini of Wallac Oy, Turku Fingland for supplying the luminometer and acessories used in this study.

The technical assistence of Frl. Sabine Seyffert, Angela Bullasch and Christine Uhlig is acknowledged for testing out the robustness of the method.

\section{References}

1. Wood, W. G., Wachter, Christine \& Scriba, P. C. (1980) Fresenius' $Z$. Anal. Chem. 301, 120.

2. Schroeder, H. R., Boguslaski, R. C., Carrico, R. J. \& Buckler, R. T. (1978) Meth. Enzymol. 57, 424-445.

3. Hersh, L. S., Vann, W. P. \& Wilhelm, S. A. (1979) Anal. Biochem. 93, 267-271.

4. Whitehead, T. P., Kricka, L. J., Carter, T. J. N. \& Thorpe, G. H: G. (1979) Clin. Chem. 25, 1531-1546.
5. Kitagawa, T. \& Aikawa, T. (1976) J. Biochem. 79, 233-236.

6. Reinsch, C. H. (1967) Numer. Math. 10, 177-183.

7. Marschner, I., Erhardt, F. W. \& Scriba, P. C. (1974) In Radioimmunoassay and related procedures in medicine, vol 1, pp. 111-122, IAEA, Vienna.

8. Wood, W. G. (1981) J. Clin. Chem. Clin. Biochem. 19, 947952 .

Dr. W. G. Wood, Ph. D.

Klinik für Innere Medizin,

Medizinische Hochschule Lübeck,

Ratzeburger Allee 160,

D-2400 Lübeck, 1 